\section{Commentary: Print another heart, practice makes perfect}

\author{
Alison F. Ward, MD, and Richard Lee, MD, MBA
}

In this edition of the Journal, Hussein and colleagues ${ }^{1}$ describe a hands-on surgical training congenital heart surgery tool for the arterial switch procedure using a 3dimensional (3D) printed model of transposition of the great arteries. They sought to objectively demonstrate an improvement in technical performance and speed with repeated practice using their model. The objective performance assessments included a procedure-based assessment, a holistic assessment, and a time-based assessment. Eighty percent of the 30 surgeons improved after their first attempt, and surgical experience did not affect performance scores. There were statistically significant improvements across all the holistic scores: fluency, knowledge, and respect for tissue. All surgeons' speed increased from their first to second attempt, with a mean improvement of $25 \%$.

The benefits of a 3D printed model are clear: a unique, anatomically precise model created to help understand the anatomic relationships of lesions and practice operations. This model is not without drawbacks, which include high printing costs and materials that do not accurately simulate human tissue, especially valve tissue. ${ }^{2-4}$ Cost and equipment requirements for $3 \mathrm{D}$ printing limit its widespread applicability, but as the authors point out, collaboration among hospitals, training programs, and even insurers could ensure widespread adoption of this training modality. Using quantitative data to demonstrate improved performance and even potentially improved outcomes will be key to continue funding simulation. In this study, although $80 \%$ of surgeons improved between attempts 1 and 2 , the authors fail to provide a realistic answer for why $20 \%$ of participants performances did not improve-citing that the surgeons potentially adopted an alternative technique on the second. With further

\footnotetext{
From the Division of Cardiothoracic Surgery, Department of Surgery, Medical College of Georgia, Augusta University, Augusta, Ga.

Disclosures: Authors have nothing to disclose with regard to commercial support.

Received for publication Dec 18, 2019; accepted for publication Dec 18, 2019; available ahead of print Jan 8, 2020.

Address for reprints: Richard Lee, MD, MBA, Department of Surgery, Medical College of Georgia, 1120 15th St, BA-4300,Augusta, GA 30912 (E-mail: RICKLEE@ augusta.edu).

J Thorac Cardiovasc Surg 2020;160:1043-4

$0022-5223 / \$ 36.00$

Copyright (c) 2020 by The American Association for Thoracic Surgery

https://doi.org/10.1016/j.jtcvs.2019.12.069
}

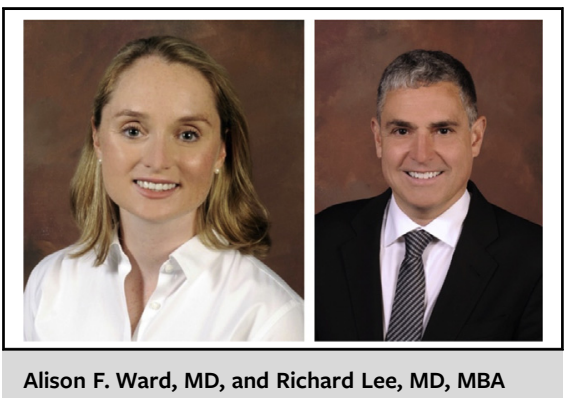

\author{
CENTRAL MESSAGE \\ Hands-on surgical training quan- \\ titatively improves surgeons' \\ techniques; continued demon- \\ stration of improved perfor- \\ mance will be needed for \\ widespread adoption in congen- \\ ital heart surgery training.
}

simulation development, the goal will need to be a higher success rate to justify widespread adoption.

The learning curve for congenital heart surgery training is steep given the technical demands of complex operations, relative rarity of individual lesions, and a small operative field, all within the time constraints of fellowship. In an era when outcomes are monitored closer than ever before, there needs to be innovation in how we train young surgeons to be proficient. Use of models on which trainees can practice and master the technical aspects of operations in a low-risk environment before the operating room, as demonstrated here, can quantitatively improve performance. The authors support the notion of increased hands-on surgical training in congenital heart surgery and take it a step further suggesting shifting the training paradigm away from number of operations toward operative competency, a thoughtprovoking idea that they believe could decrease the training time-an unrealistic idea.

3D printed models provide a hands-on simulation tool for congenital heart surgeons and trainees. More studies, like this one, will need to demonstrate quantitatively improved performance to promote widespread adoption within the congenital heart surgery training paradigm.

\section{References}

1. Hussein N, Honjo O, Haller C, Coles JG, Hua Z, Van Arsdell G, et al. Quantitative assessment of technical performence during hands-on surgical training of the arterial switch operation using 3-dimensional printed heart models. J Thorac Cardiovasc Surg. 2020;160:1035-42. 
2. Hussein N, Honjo O, Haller C, Hickey E, Coles JG, Williams WG, et al. Hands-on surgical simulation in congenital heart surgery: literature review and future perspective. Semin Thorac Cardiovasc Surg. 2019 [Epub ahead of print].

3. Scanlan AB, Nguyen AV, Ilina A, Lasso A, Cripe L, Jegatheeswaran A, et al. Comparison of 3D echocardiogram-derived $3 \mathrm{D}$ printed valve models to molded models for simulated repair of pediatric atrioventricular valves. Pediatr Cardiol. 2018;39: 538-47.

4. Yoo SJ, Spray T, Austin EH III, Yun TJ, van Arsdell GS. Hands-on surgical training of congenital heart surgery using 3-dimensional print models. J Thorac Cardiovasc Surg. 2017;153:1530-40.
See Article page 1035

\section{Commentary: Operate on my printed model - absolutely; my newborn grandchild?}

\author{
Ronald K. Woods, MD, PhD
}

Training of pediatric cardiac surgeons and mentoring junior surgeons-mission vital, yet not easy to do. The difficulty is inherent to the low- (or no) error margin in many of the procedures we do. Let's suppose you are an experienced surgeon with a newborn grandchild with transposition of the great arteries (TGA) and ventricular septal defect (VSD). You are to advise your son or daughter to choose between surgeon A, who trained at a reputable program, met all certification criteria (remarkably did 10 mentored TGA/VSD procedures during training), and is in year 1 in practice. As faculty, surgeon A has done 2 mentored repairs with excellent results. Surgeon A will now operate independently with a senior mentor readily available. Your other option is surgeon $\mathrm{B}$, who has done 70 repairs with excellent results. Your advice? And that is the essence of our challenge. In part, this highlights the importance of the work by the group in Toronto, who has invested considerably in expertise and infrastructure to enable the incorporation of 3-dimensional (3D) training models into their curriculum. They now provide an assessment tool and demonstrate that practicing the arterial switch on a 3D TGA model can result in

\footnotetext{
From the Division of Pediatric Cardiothoracic Surgery, Department of Surgery, Medical College of Wisconsin, and Herma Heart Institute, Children's Wisconsin, Milwaukee, Wis.

Disclosures: Author has nothing to disclose with regard to commercial support.

Received for publication Jan 23, 2020; accepted for publication Jan 24, 2020; available ahead of print Feb 8, 2020.

Address for reprints: Ronald K. Woods, MD, PhD, Division of Pediatric Cardiothoracic Surgery, Department of Surgery Medical College of Wisconsin, Children's Wisconsin, 9000 W Wisconsin Ave, MS B 730, Milwaukee, WI 53226 (E-mail: rwoods@chw.org).

J Thorac Cardiovasc Surg 2020;160:1044-5

$0022-5223 / \$ 36.00$

Copyright (c) 2020 by The American Association for Thoracic Surgery

https://doi.org/10.1016/j.jtcvs.2020.01.069
}

Check for updates

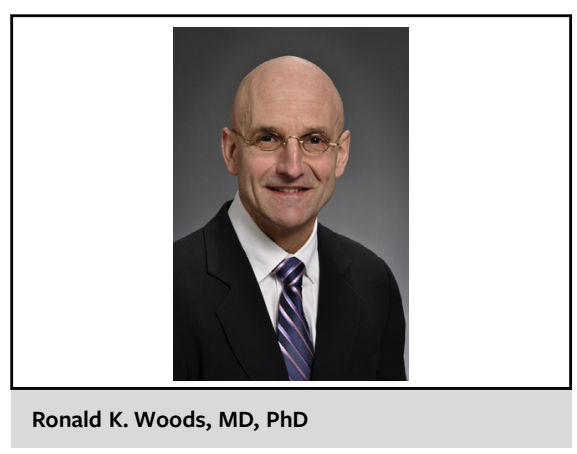

CENTRAL MESSAGE

Procedural training on 3D-

printed models may enhance

knowledge and technical perfor-

mance of selected congenital

cardiac surgical procedures.

performance improvement. ${ }^{1}$ Despite numerous challenges, I suspect most, if not all accredited training programs will incorporate this type of training as part of their curriculum at some point in the future, even if simply by sending trainees to specialized "boot camps." Although possibly limited to a handful of common anomalies, it couldn't hurt (except maybe some money), and it may well help.

But does the number of 3D model procedures or scores influence your choice of surgeon?

Suppose you are the surgical director of a 150 pump case/ year program and do 2 to 4 TGA/VSD procedures per year. Your denominator is low-one little mishap could impact your percentage for the next several reporting cycles. At what point do you allow your junior partner to be the primary surgeon? At what point do you step away from mentoring every detail of the case? What feedback are you getting from your cardiologists? These are incredibly important questions, and the answers have incredibly important implications for Surgeon A maturing to Surgeon B. The solution may not be easy, but it isn't magic-it requires available, willing, competent mentors who will stand 